\title{
Design of Digital Test Using Wondershare in Supporting the Blended Learning with Kelase Platform
}

\author{
I Wayan Eka Mahendra ${ }^{1}$, I Gusti Ngurah Agung Trisna Jayantika ${ }^{1}$, I Wayan Sumandya ${ }^{\mathbf{1}}$, Ni Made \\ Suarni $^{2}$, Ni Wayan Ariawati², Gusti Ayu Dessy Sugiharni ${ }^{3}$, Dewa Gede Hendra Divayana, ${ }^{4}$ * \\ ${ }^{1}$ Department of Mathematics Education, Institut Keguruan dan Ilmu Pendidikan PGRI Bali, Indonesia \\ ${ }^{2}$ Department of Language, Institut Keguruan dan Ilmu Pendidikan PGRI Bali, Indonesia \\ ${ }^{3}$ Department of Mathematics Education, Institut Teknologi dan Bisnis STIKOM Bali, Indonesia \\ ${ }^{4}$ Department of Information Technology Education, Universitas Pendidikan Ganesha, Indonesia
}

Received December 24, 2019; Revised January 28, 2020; Accepted February 7, 2020

Copyright $\odot 2020$ by authors, all rights reserved. Authors agree that this article remains permanently open access under the terms of the Creative Commons Attribution License 4.0 International License

\begin{abstract}
This research was aimed to provide an overview of digital test design that created using the Wondershare application and then imported into the Kelase platform to realize good blended learning to improve students' cognitive abilities. The approach of this research was development research, which focused on developing digital test instruments. The stages of development include: making the instrument items, validating the contents of instrument items, analyzing the instrument items, making the final items, importing the final items to Wondershare, and importing the digital tests to the Kelase platform. The research subjects that were involved in simulating content validation were two experts. Item analysis was done by determining the score of content validation and that score then compared with the validity categorization table that refers to Guilford. The validation score of the instrument contents was 0.850 , so it was classified as excellent validity. The results of this research showed that 17 final items were imported into the Wondershare application and the Kelase platform, while three items were removed.
\end{abstract}

Keywords Digital Test, Wondershare, Blended Learning, Kelase

\section{Introduction}

The education quality is determined mostly by the support of adequate infrastructure and facilities of learning. This statement is supported by the research results that were conducted by Taneri and Engin-Demir in 2011 [1], which stated that good quality in education could not be achieved if adequate infrastructure and facilities do not support it.

At present, learning facilities, and infrastructure in the form of organizing an information technology-based learning model is essential because it can overcome the time and distance problems that are generally occurred in conventional learning processes. This statement is strengthened from the research results that were conducted by Tigowati, Efendi, and Budiyanto in 2017 [2] which stated that e-learning as one of the IT-based learning model has been able to overcome the constraints of time and distance in conventional learning through a full online-based learning process.

Some IT-based learning models such as e-learning, blended learning, virtual learning have also been encountered in vocational high schools or universities in the IT field to support the learning process. Those learning models can work well as long as they are supported by facilities/platforms, teaching media, teaching materials, and adequate types of tests.

Facts were seen in the field, showed that learning models, such as blended learning that still had not been maximally applied, especially in the learning process in some senior high schools or vocational high schools [3]. That thing occurred because the selection of platform types that had not been right, the content of teaching materials was incomplete, and the most important was the form of digital tests that wasn't packaged well so that students lack understanding in depth about the material learned.

Criteria of good digital test used in IT-based learning models are tests that can measure the cognitive domain of students as a whole, starting from the basic thinking level to the critical thinking level, even though the process is done in full online or semi-online. In addition to these criteria, it should also be noted the application that is used in making digital tests must be compatible with the 
learning model platforms.

Therefore, in organizing blended learning requires high dedication from various parties. That following the statement of Lalima and Dangwal in 2017 [4], which stated that the implementation of blended learning must get full support from the managerial side.

Based on the facts, problems that was found in the field and several digital test standard criteria that was expected to realize the running of IT-based learning models optimally, then the innovation that was offered in the form of utilizing the Wondershare application in making the digital tests and the Kelase platform as a container for implementing the digital tests that had been formed so that later be able to realize the optimal blended learning model. Based on those things, so the problem statement of this research was how the digital test design was created with Wondershare and its implementation mechanism through the Kelase platform?

Some of the research results underlying this research were the research that was conducted by Rahayuet al. in 2018 [5] that showed the use of the Wondershare quiz creator application to make digital tests in supporting the realization of Mathematics learning media, particularly in terms of its evaluation. The obstacle in Rahayuet al.'s research wasn't showed a digital test that had been arranged in stages, starting from the lowest difficulty level to the highest difficulty level. Research that was conducted by Llorens, Nevin, and Mageean in 2014 [6] showed the application of Wondershare as one of the platforms that can be used to make online quizzes, but the limitation found in their research was hadn't demonstrated a simulation of the test making process that was entered into that Wondershare platform.

The research result that was conducted by Jackman in 2018 [7] showed that the application of Wondershare could be used to support blended learning. However, the limitation of Jackman's research wasn't yet explained in detail about the process of making digital tests using the Wondershare application. The research result that was conducted by Helsa and Kenedi in 2019 [8] showed the use of Edmodo in facilitating the realization of blended learning for Mathematics. However, the limitation of Helsa and Kenedi's research wasn't yet shown the form of the test instrument was used to evaluate the level of cognitive abilities of students in following the Mathematics learning process using Edmodo-based blended learning. The research result that was conducted by Divayana in 2019 [9] showed that the Kelase platform could be used to realize the blended learning model in the Assessment and Evaluation course. But in Divayana's research had not been explained the compatibility of the Wondershare application in presenting the digital test required in Kelase-based blended learning.

\section{Methodology}

This research was an instrument development research, which consists of several stages, including 1) making the instrument items, 2) validating the instrument items, 3) analyzing the instrument items, 4) determining the final items, 5) inserting the final items into the Wondershare application, 6) entering digital test into the Kelase platform. Explicitly, in this study, the instrument items which used were simulated using the symbols $X_{1}$ to $X_{20}$. Two informatics engineering education experts were involved in simulating the content validation test of the instrument. Instrument items were analyzed using the Gregory formula, which followed equation (1) [10] and interpreted refers to Guilford's categorization that fully can be seen in Table 1 [11].

$$
\text { Content validity }=\frac{D}{A+B+C+D}
$$

$\mathrm{A}=$ cell that shows the disagreement between the two evaluators

$\mathrm{B}$ and $\mathrm{C}=$ cell that shows the differences of view between two evaluators

$\mathrm{D}=$ cell that shows the valid agreement between the two evaluators

Table 1. Categorization of Instrument Validation According to Guilford

\begin{tabular}{|c|c|}
\hline Category & Score Range \\
\hline Excellent validity & $1.00 \geq \mathrm{r}_{\mathrm{xy}}>0.80$ \\
\hline Good validity & $0.80 \geq \mathrm{r}_{\mathrm{xy}}>0.60$ \\
\hline Moderate validity & $0.60 \geq \mathrm{r}_{\mathrm{xy}}>0.40$ \\
\hline Less validity & $0.40 \geq \mathrm{r}_{\mathrm{xy}}>0.20$ \\
\hline Poor validity & $0.20 \geq \mathrm{r}_{\mathrm{xy}}>0.00$ \\
\hline Invalid & $0.00 \geq \mathrm{r}_{\mathrm{xy}}$ \\
\hline
\end{tabular}

The final items were determined based on valid instrument items. Those items were entered into the Wondershare application by following the item types provided in the Wondershare application. Digital tests that had been formed from the Wondershare application could then be incorporated into blended learning through the Kelase platform.

\section{Results \& Discussion}

\subsection{Digital Test Instrument Items}

The items of digital test instruments simulated with $X_{1}$ to $X_{20}$ can be seen in Table 2. The items $X_{1}$ to $X_{20}$ were arranged based on the difficulty level of the questions. 
Table 2. Simulation of Digital Test Instrument Items

\begin{tabular}{|c|c|c|}
\hline No. & Items & Difficulty Level \\
\hline 1. & $\mathrm{X}_{1}$ & Basic \\
\hline 2. & $\mathrm{X}_{2}$ & Basic \\
\hline 3. & $\mathrm{X}_{3}$ & Basic \\
\hline 4. & $\mathrm{X}_{4}$ & Basic \\
\hline 5. & $\mathrm{X}_{5}$ & Basic \\
\hline 6. & $\mathrm{X}_{6}$ & Basic \\
\hline 7. & $\mathrm{X}_{7}$ & Basic \\
\hline 8. & $\mathrm{X}_{8}$ & Midle \\
\hline 9. & $\mathrm{X}_{9}$ & Intermediate \\
\hline 10. & $\mathrm{X}_{10}$ & Intermediate \\
\hline 11. & $\mathrm{X}_{11}$ & Intermediate \\
\hline 12. & $\mathrm{X}_{12}$ & Intermediate \\
\hline 13. & $\mathrm{X}_{13}$ & Intermediate \\
\hline 14. & $\mathrm{X}_{14}$ & Intermediate \\
\hline 15. & $\mathrm{X}_{15}$ & Intermediate \\
\hline 16. & $\mathrm{X}_{16}$ & Intermediate \\
\hline 17. & $\mathrm{X}_{17}$ & Masterly \\
\hline 18. & $\mathrm{X}_{18}$ & Masterly \\
\hline 19. & $\mathrm{X}_{19}$ & Masterly \\
\hline 20. & $\mathrm{X}_{20}$ & Masterly \\
\hline & & \\
\hline
\end{tabular}

Table 3. Results Simulation the Content Validity of Instrument Items by Expert-1

\begin{tabular}{|c|c|c|c|c|c|}
\hline \multirow{2}{*}{ No } & \multirow{2}{*}{ Items } & \multicolumn{4}{|c|}{ Validation Score } \\
\hline & & \multicolumn{2}{|c|}{ Irrelevant } & \multicolumn{2}{c|}{ Relevant } \\
\hline & & $\mathbf{1}$ & $\mathbf{2}$ & $\mathbf{3}$ & $\mathbf{4}$ \\
\hline 1 & $\mathrm{X}_{1}$ & & & $\sqrt{ }$ & \\
\hline 2 & $\mathrm{X}_{2}$ & $\sqrt{ }$ & & & \\
\hline 3 & $\mathrm{X}_{3}$ & & & & $\sqrt{ }$ \\
\hline 4 & $\mathrm{X}_{4}$ & & & & $\sqrt{ }$ \\
\hline 5 & $\mathrm{X}_{5}$ & & & $\sqrt{ }$ & \\
\hline 6 & $\mathrm{X}_{6}$ & & & $\sqrt{ }$ & \\
\hline 7 & $\mathrm{X}_{7}$ & & & $\sqrt{ }$ & \\
\hline 8 & $\mathrm{X}_{8}$ & & & & $\sqrt{ }$ \\
\hline 9 & $\mathrm{X}_{9}$ & & $\sqrt{ }$ & & \\
\hline 10 & $\mathrm{X}_{10}$ & & & $\sqrt{ }$ & \\
\hline 11 & $\mathrm{X}_{11}$ & & & $\sqrt{ }$ & \\
\hline 12 & $\mathrm{X}_{12}$ & & & & $\sqrt{ }$ \\
\hline 13 & $\mathrm{X}_{13}$ & & & & $\sqrt{ }$ \\
\hline 14 & $\mathrm{X}_{14}$ & & & & $\sqrt{ }$ \\
\hline 15 & $\mathrm{X}_{15}$ & & & & $\sqrt{ }$ \\
\hline 16 & $\mathrm{X}_{16}$ & & & & $\sqrt{ }$ \\
\hline 17 & $\mathrm{X}_{17}$ & & & $\sqrt{ }$ & \\
\hline 18 & $\mathrm{X}_{18}$ & & & & \\
\hline 19 & $\mathrm{X}_{19}$ & & & $\sqrt{ }$ & \\
\hline 20 & $\mathrm{X}_{20}$ & & & $\sqrt{ }$ & \\
\hline & & & & & \\
\hline & & & & & \\
\hline
\end{tabular}

Table 4. Results Simulation the Content Validity of Instrument Items by Expert-2

\begin{tabular}{|c|c|c|c|c|c|}
\hline \multirow{2}{*}{ No } & \multirow{2}{*}{ Items } & \multicolumn{4}{|c|}{ Validation Score } \\
\hline & & Irrelevant & \multicolumn{2}{c|}{ Relevan } \\
\hline & & $\mathbf{1}$ & $\mathbf{2}$ & $\mathbf{3}$ & $\mathbf{4}$ \\
\hline 1 & $\mathrm{X}_{1}$ & & & & $\sqrt{ }$ \\
\hline 2 & $\mathrm{X}_{2}$ & & $\sqrt{ }$ & & \\
\hline 3 & $\mathrm{X}_{3}$ & & & & $\sqrt{ }$ \\
\hline 4 & $\mathrm{X}_{4}$ & & & & $\sqrt{ }$ \\
\hline 5 & $\mathrm{X}_{5}$ & & & $\sqrt{ }$ & \\
\hline 6 & $\mathrm{X}_{6}$ & & & & $\sqrt{ }$ \\
\hline 7 & $\mathrm{X}_{7}$ & & & $\sqrt{ }$ & \\
\hline 8 & $\mathrm{X}_{8}$ & & & & $\sqrt{ }$ \\
\hline 9 & $\mathrm{X}_{9}$ & $\sqrt{ }$ & & & \\
\hline 10 & $\mathrm{X}_{10}$ & & & & $\sqrt{ }$ \\
\hline 11 & $\mathrm{X}_{11}$ & & & & $\sqrt{ }$ \\
\hline 12 & $\mathrm{X}_{12}$ & & & & $\sqrt{ }$ \\
\hline 13 & $\mathrm{X}_{13}$ & & & & $\sqrt{ }$ \\
\hline 14 & $\mathrm{X}_{14}$ & & & $\sqrt{ }$ & \\
\hline 15 & $\mathrm{X}_{15}$ & & & $\sqrt{ }$ & \\
\hline 16 & $\mathrm{X}_{16}$ & & & & $\sqrt{ }$ \\
\hline 17 & $\mathrm{X}_{17}$ & & & $\sqrt{ }$ & \\
\hline 18 & $\mathrm{X}_{18}$ & $\sqrt{ }$ & & & \\
\hline 19 & $\mathrm{X}_{19}$ & & & & $\sqrt{ }$ \\
\hline 20 & $\mathrm{X}_{20}$ & & & $\sqrt{ }$ & \\
\hline & & & & & \\
\hline & & & & & \\
\hline
\end{tabular}

\subsection{The Results of the Instruments Content Validation}

The simulation results of the item content validation given by experts can be shown in Table 3 and Table 4 . The item content validation score was in the range of 1 to 4 . The range score was 1 to 2 for the irrelevant score, while the score range was 3 to 4 for the relevant score.

\subsection{The Results of Instrument Analysis}

The results of the instrument content validation that had been carried out by the two experts shown in Table 3 and Table 4, then was analyzed using the Gregory formula calculation to obtain a content validation score. The content validation score using the Gregory formula calculation refers to the data shown in Table 5 and Table 6.

Table 5. Compilation of Instruments Content Validation Test Results by Both Experts

\begin{tabular}{|c|c|c|c|}
\hline \multicolumn{2}{|c|}{ Expert-1 } & \multicolumn{2}{c|}{ Expert-2 } \\
\hline $\begin{array}{c}\text { Irrelevant } \\
\text { (Score 1 - 2) }\end{array}$ & $\begin{array}{c}\text { Relevant } \\
\text { (Score 3 - 4) }\end{array}$ & $\begin{array}{c}\text { Irrelevant } \\
\text { (Score 1 - 2) }\end{array}$ & $\begin{array}{c}\text { Relevant } \\
\text { (Score 3 - 4) }\end{array}$ \\
\hline & $\mathrm{X}_{1}, \mathrm{X}_{3}, \mathrm{X}_{4}$, & & $\mathrm{X}_{1}, \mathrm{X}_{3}, \mathrm{X}_{4}$, \\
& $\mathrm{X}_{5}, \mathrm{X}_{6}, \mathrm{X}_{7}$, & & $\mathrm{X}_{5}, \mathrm{X}_{6}, \mathrm{X}_{7}$, \\
& $\mathrm{X}_{8}, \mathrm{X}_{10}, \mathrm{X}_{11}$, & $\mathrm{X}_{2}, \mathrm{X}_{9}, \mathrm{X}_{18}$ & $\mathrm{X}_{8}, \mathrm{X}_{10}, \mathrm{X}_{11}$, \\
$\mathrm{X}_{2}, \mathrm{X}_{9}, \mathrm{X}_{18}$ & $\mathrm{X}_{12}, \mathrm{X}_{13}, \mathrm{X}_{14}$, \\
& $\mathrm{X}_{13}, \mathrm{X}_{14}$, & & $\mathrm{X}_{15}, \mathrm{X}_{16}, \mathrm{X}_{17}$, \\
& $\mathrm{X}_{15}, \mathrm{X}_{16}, \mathrm{X}_{17}$, & & $\mathrm{X}_{19}, \mathrm{X}_{20}$ \\
\hline
\end{tabular}


Table 6. Cross Tabulation of Instrument Content Validation Test Results by Both Experts

\begin{tabular}{|c|c|c|c|}
\hline \multicolumn{2}{|c|}{} & \multicolumn{2}{|c|}{ Expert-2 } \\
\cline { 2 - 4 } \multicolumn{1}{|c|}{} & $\begin{array}{c}\text { Irrelevant } \\
\text { (Score 1 - 2) }\end{array}$ & $\begin{array}{c}\text { Relevant } \\
\text { (Score 3 - 4) }\end{array}$ \\
\hline \multirow{4}{*}{ Expert-1 } & $\begin{array}{c}\text { Irrelevant } \\
\text { (Score 1 - 2) }\end{array}$ & $\begin{array}{c}\mathrm{A} \\
\mathrm{X}_{2}, \mathrm{X}_{9}, \mathrm{X}_{18}\end{array}$ & $\begin{array}{c}\mathrm{B} \\
(3)\end{array}$ \\
\cline { 2 - 4 } & & $\mathrm{C}$ & $(0)$ \\
& & & $\mathrm{D}$ \\
& Relevant & & $\mathrm{X}_{1}, \mathrm{X}_{3}, \mathrm{X}_{4}, \mathrm{X}_{5}, \mathrm{X}_{6}$, \\
& & $\mathrm{X}_{7}, \mathrm{X}_{8}, \mathrm{X}_{10}, \mathrm{X}_{11}$, \\
& (Score 3 - 4) & - & $\mathrm{X}_{12}, \mathrm{X}_{13}, \mathrm{X}_{14}, \mathrm{X}_{15}$, \\
& & & $\mathrm{X}_{16}, \mathrm{X}_{17}, \mathrm{X}_{19}, \mathrm{X}_{20}$ \\
& & $(0)$ & $(17)$ \\
\hline
\end{tabular}

Based on the tabulation results shown in table 6 , the content validation calculation can be done using Gregory as follows.

$$
\begin{aligned}
\text { Content Validity } & =\frac{\mathrm{D}}{\mathrm{A}+\mathrm{B}+\mathrm{C}+\mathrm{D}} \\
& =\frac{17}{3+0+0+17} \\
& =\frac{17}{20}=0.850
\end{aligned}
$$

The content validation score was 0.850 showed that the instrument items of the digital test were categorized as good when viewed from the Guilford categorization that previously shown in Table 1 .

\subsection{Final Instrument Items}

Based on the instrument analysis results, the items that must be discarded, and the items that were still used can be determined. Items that were not relevant according to

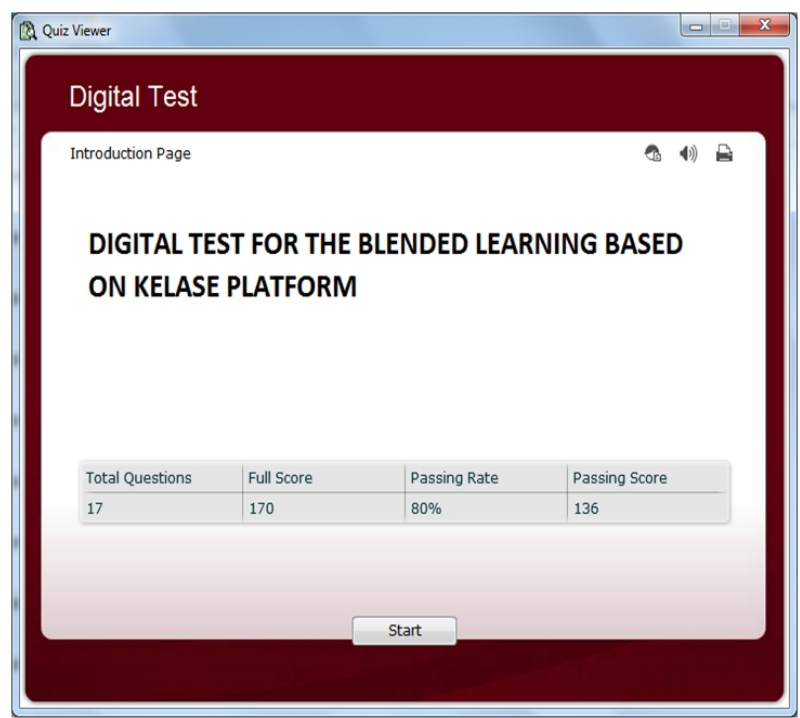

expert judgment must be discarded, while relevant items can still be used. The complete final items used can be shown in Table 7.

Table 7. The Final Instrument Items of Digital Test

\begin{tabular}{|c|c|c|}
\hline No. & Items & Decision \\
\hline 1. & $\mathrm{X}_{1}$ & Used \\
\hline 2. & $\mathrm{X}_{2}$ & Discarded \\
\hline 3. & $\mathrm{X}_{3}$ & Used \\
\hline 4. & $\mathrm{X}_{4}$ & Used \\
\hline 5. & $\mathrm{X}_{5}$ & Used \\
\hline 6. & $\mathrm{X}_{6}$ & Used \\
\hline 7. & $\mathrm{X}_{7}$ & Used \\
\hline 8. & $\mathrm{X}_{8}$ & Used \\
\hline 9. & $\mathrm{X}_{9}$ & Discarded \\
\hline 10. & $\mathrm{X}_{10}$ & Used \\
\hline 11. & $\mathrm{X}_{11}$ & Used \\
\hline 12. & $\mathrm{X}_{12}$ & Used \\
\hline 13. & $\mathrm{X}_{13}$ & Used \\
\hline 14. & $\mathrm{X}_{14}$ & Used \\
\hline 15. & $\mathrm{X}_{15}$ & Used \\
\hline 16. & $\mathrm{X}_{16}$ & Used \\
\hline 17. & $\mathrm{X}_{17}$ & Used \\
\hline 18. & $\mathrm{X}_{18}$ & Discarded \\
\hline 19. & $\mathrm{X}_{19}$ & Used \\
\hline 20. & $\mathrm{X}_{20}$ & Used \\
\hline
\end{tabular}

\subsection{Import the Final Items into the Wondershare Application}

Items that were ready to be used for digital test instruments can be entered into the Wondershare application through templates and question formats that were already available in the application. The display of items that had been entered into the Wondershare application can be shown in Figure 1.

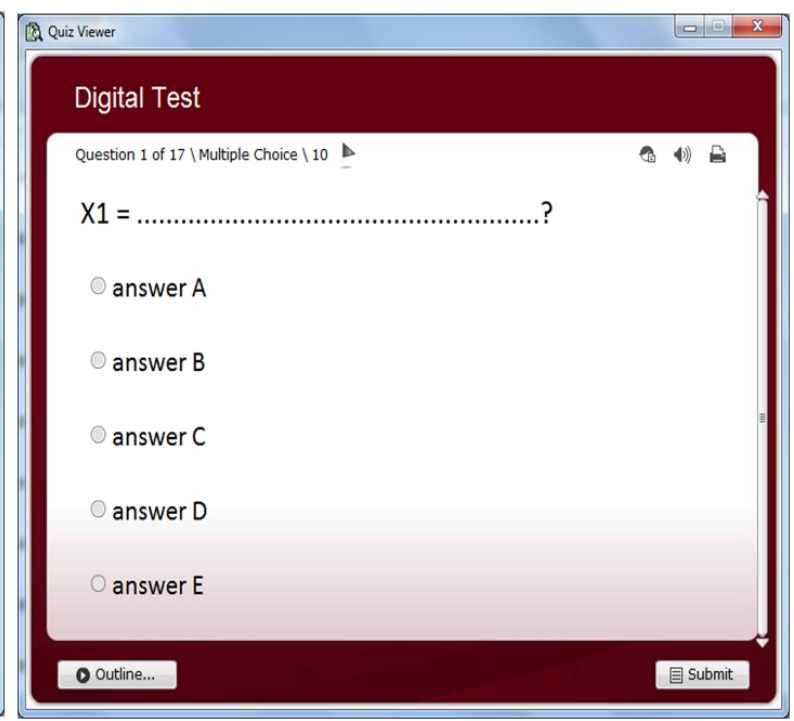

Figure 1. The Display of Final Instruments in Wondershare Application 


\subsection{Import the Digital test into the Kelase Platform}

Digital tests that had been successfully created using the Wondershare application then imported into the Kelase platform. Way to import these digital tests into the Kelase platform was through the added facility of "question bank" that was found on the Kelase platform. The inserting process display of the digital test into the Kelase platform can be seen in Figure 2, while the display of the digital tests that had been included in the Kelase platform can be shown in Figure 3.

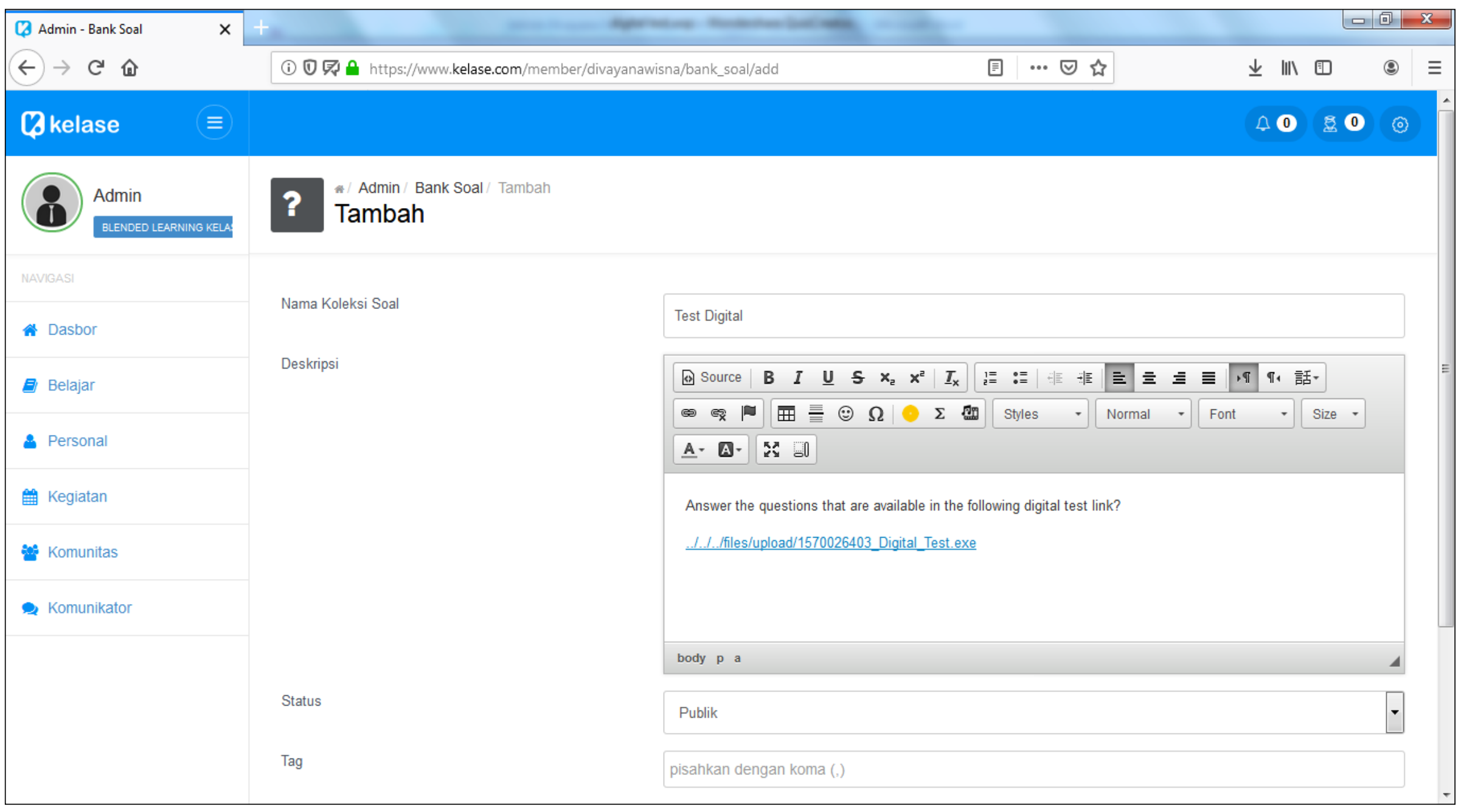

Figure 2. Display of Process Import the Digital Test to the Kelase Platform 


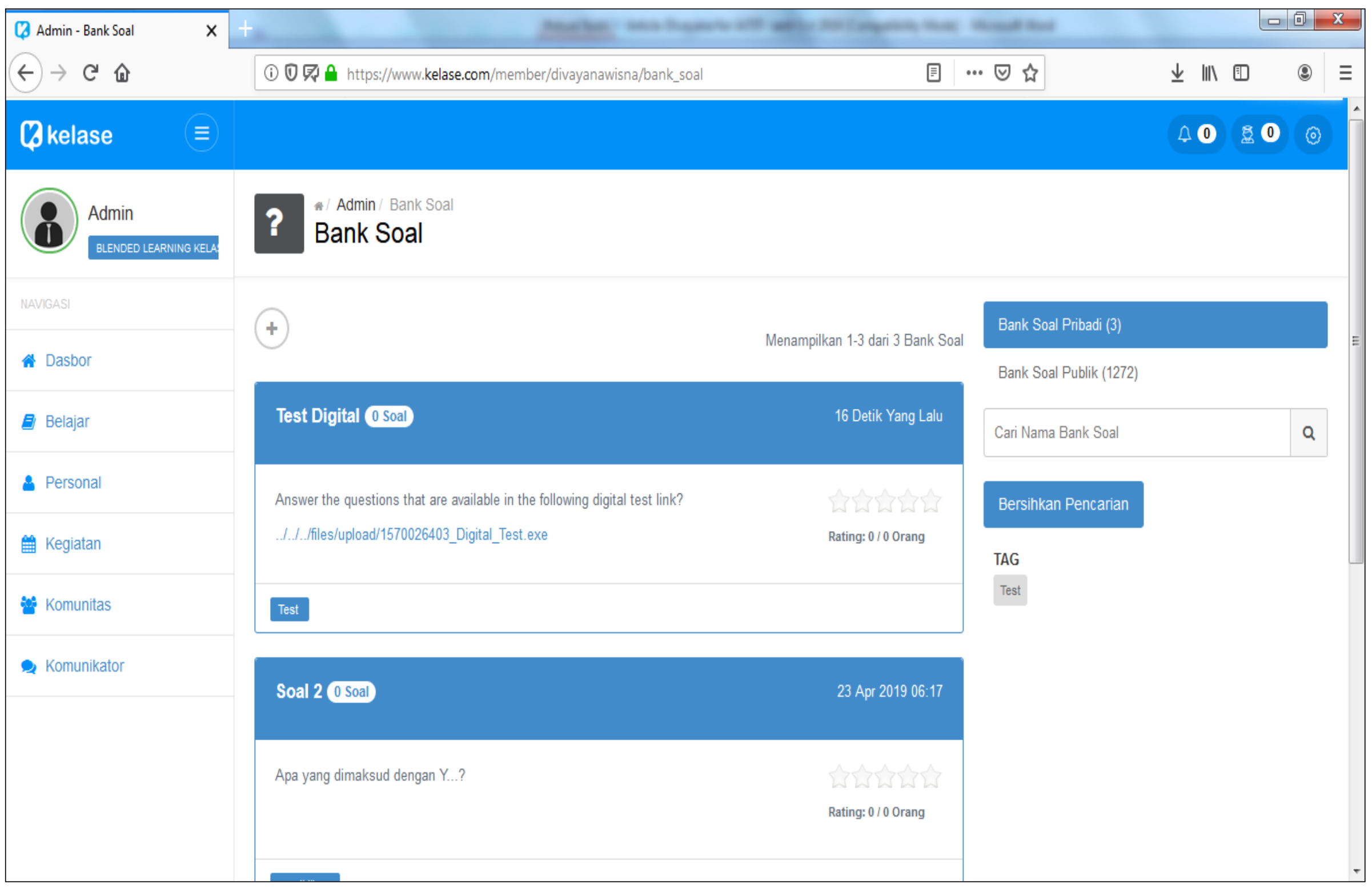

Figure 3. Display of the Digital Test which is Already in the Kelase Platform 
Based on the results shown in Table 7, it seems clear that there are 17 final items used and imported into the Wondershare application to become a digital test, while three items other that black-blocked must be discarded. The novelty of this research is to provide information on how to make digital instruments using the Wondershare application that is compatible with the Kelase platform so that the formed digital test instruments can be accessed easily through the Kelase platform. Besides that, through this research, digital test instruments that were obtained that can measure the cognitive abilities of students from the basic level to the high level in following the learning process using a blended learning model based on Kelase platform.

The results of this research were able to answer the limitation that was found in Rahayuet al. and Helsa and Kenedi's research by showed a simulation of digital test instruments specifically to measure the cognitive domains of students which had been shown fully in Table 2 and supplemented by difficulty level of the test items from the basic level to advanced level. The results of this research had also answered the research limitation of Llorens, Nevin, and Mageean and Jackman by showed a simulation of making the digital tests that had been shown in Table 2 to Table 7 and the results of import tests into the Wondershare application shown in Figure 1.

The results of this research were able to answer the limitation of Divayana's research by showed Figure 2 and Figure 3 as evidence of compatibility the digital test based on Wondershare that was incorporated into the Kelase platform. The obstacle in this research wasn't detailed yet describing the digital instrument items used in measuring student's learning outcomes in the cognitive, affective, and psychomotor domains.

\section{Conclusions}

The digital test design that is created using the Wondershare application is easy to make, and compatible is implemented on one of the blended learning platform, namely Kelase. This thing is evidenced from the results of the final instrument items as many as 17 items that had obtained from the instrument content validation calculation are easily entered into the Wondershare application and then compatible with "question bank" facilities contained on the Kelase platform. The solution that can be done to solve the obstacle in this research is an innovation that can show the details of each instrument by adopting the Tri Kaya Parisudha concept so that it can measure the cognitive, affective, and psychomotor domains in the learning process using blended learning.

\section{Acknowledgements}

The researchers would like to express their sincere thanks to all those who had provided opportunities and support for the completion of this research.

\section{REFERENCES}

[1] P.O.Taneri, and C. Engin-Demir. (2011). Quality of Education in Rural Schools: A Needs Assessment Study (Ankara-Kalecik Sample). International Online Journal of Educational Sciences, Vol. 3. No. 1, 91-112.

[2] Tigowati, A. Efendi, and C. Budiyanto. (2017). The Influence of the Use of E-learning to Student Cognitive Performance and Motivation in Digital Simulation Course. Indonesian Journal of Informatics Education, Vol. 1. No. 2, 41-48.

[3] A.R. Zain, and Jumadi. (2018). Effectiveness of Guided Inquiry Based on Blended Learning in Physics Instruction to Improve Critical Thinking Skills of the Senior High School Student. In:The 5th International Conference on Research, Implementation, \& Education of Mathematics and Sciences, IOP Conf. Series: Journal of Physics Conference Series, Vol. 1097, 1-6.

[4] Lalima, and K.L. Dangwal. (2017). Blended Learning: An Innovative Approach. Universal Journal of Educational Research, Vol. 5. No. 1, 129-136.

[5] Y.N. Rahayu, R. Kariadinata, Z. Fariansyah, R. P. Yaniawati, and H. Sugilar. (2018). Development of Instructional Multimedia for Mathematics Based on Adobe Flash and Wondershare Quiz Creator. In:3rd Annual Applied Science and Engineering Conference (AASEC 2018), IOP Conf. Series: Materials Science and Engineering, Vol. 434, 1-5.

[6] M. Llorens, E. Nevin, and E. Mageean. (2014). Online Resource Platform for Mathematics Education. In: Proceedings 44th Annual Frontiers in Education (FIE) Conference, 1865-1872.

[7] W.M. Jackman. (2018). Switching from Traditional to Blended Learning at University Level: Students' and Lecturers' Experiences. International Journal of Learning, Teaching and Educational Research, Vol. 17, No. 5, 1-14.

[8] Y. Helsa, and A.K. Kenedi. (2019). Edmodo-Based Blended Learning Media in Learning Mathematics. Journal of Teaching and Learning in Elementary Education (JTLEE), Vol. 2. No. 2, 107-117.

[9] D.G.H. Divayana. (2019). The Implementation of Blended Learning with Kelase Platform in the Learning of Assessment and Evaluation Course," International Journal of Emerging Technologies in Learning (iJET), Vol. 14. No. 17, 114-132.

[10] N. Sugihartini, G.P. Sindu, K.S. Dewi, M. Zakariah, and P. Sudira. (2019). Improving Teaching Ability with Eight Teaching Skills. In: 3rd International Conference on Innovative Research Across Disciplines (ICIRAD 2019), Advances in Social Science, Education and Humanities Research, Vol. 394, 306-310.

[11] A. Fazlina. (2018). An Analysis of College Entrance Test. English Education Journal, Vol. 9, No. 2, 192-215. 